\title{
Correlation studies on available sulphur and soil properties in soils of Dabhra block under Janjgir- Champa district in Chhattisgarh
}

\author{
HAREESH KUMAR, K.K. SAHU, P.K. KURRE, R.G. GOSWAMI AND C.D. KURREY
}

Received : 28.06.2014; Revised : 08.10.2014; Accepted : 25.10 .2014

\section{MEMBERS OF RESEARCH FORUM \\ Corresponding author : HAREESH KUMAR, Department of Soil Science and Agricultural Chemistry, Indira Gandhi Agricultural University, RAIPUR (C.G.) INDIA Email: hareeshkunwaar@gmail.com}

Co-authors :

K.K. SAHU, P.K. KURRE, R.G. GOSWAMI AND C.D. KURREY, Department of Soil Science and Agricultural Chemistry, Indira Gandhi Agricultural University, RAIPUR (C.G.) INDIA

\begin{abstract}
Summary
The study was carried out for evaluation of soil fertility with respect to available sulphur status and its relationship with important physico-chemical characteristics in red and yellow soil of Dabhra block under Janjgir district of Chhattisgarh during 2013-14. Grid based surface (0-15 cm depth) soil samples were collected using global positioning system (GPS) from 126 villages from every 10 ha land area. The soil result revealed that $\mathrm{pH}$ varied from $4.1-8.4$ (mean 5.7) and indicated that soils were found to be acidic to slightly alkaline in reaction. The electrical conductivity (EC) varied from 0.01 to $0.97 \mathrm{dS} \mathrm{m}^{-1}$ with a mean value of $0.16 \mathrm{dS} \mathrm{m}^{-1}$ at $25^{\circ} \mathrm{C}$ of the Dabhra block. The total salt content of these soils, expressed as EC, were categorized as $<0.1,0.1$ to $0.2,0.2$ to 0.3 and $>0.3 \mathrm{dSm}^{-1}$. The soil ranged from $0.01-1.3$ with a mean value of organic carbon 0.57 per cent, about 52.66 per cent soil of this block came under medium, 31.75 per cent sample under low and only 14.29 per cent sample had high range of fertility group. The soil was high in available $\mathrm{S}$ content. It ranged from 7.28 to $89.6 \mathrm{~kg}$ $\mathrm{ha}^{-1}$ with an average of $35.02 \mathrm{~kg} \mathrm{ha}^{-1}$. The available $\mathrm{S}$ in more than 44.37 per cent soil sample was classified as high, 21.89 per cent sample under medium and 33.72 per cent sample in low fertility class under fertility group. The correlation between available $\mathrm{S}$ and soil properties showed negative significant correlation with $\mathrm{pH}$ and positive significant correlation with OC.
\end{abstract}

Key words : Correlation, Sulphur status, pH, EC, Organic carbon

How to cite this article : Kumar, Hareesh, Sahu, K.K., Kurre, P.K. Goswami, R.G and Kurrey, C.D. (2014). Correlation studies on available sulphur and soil properties in soils of Dabhra block under Janjgir-Champa district in Chhattisgarh. Asian J. Soil Sci., 9(2): 217-220. 